\title{
The Financial Services (Banking Reform) Act 2013: Smart Regulatory Regime?
}

\author{
Muhammed Korotana*
}

\begin{abstract}
The Financial Services (Banking Reform) Act 2013 includes the government's reform of the banking industry regarding 'ring-fencing' and the 'electrification' of the ringfence. The ring-fencing provisions in the Act are based on Sir John Vickers' Report and the recommendations from the Parliamentary Commission on Banking Standards (PCBS). The PCBS argument was that the envisaged 'ring-fence' regulation in the Bill, based on Sir John Vickers' report, fell short of expectations, and would be easily breached by unscrupulous bankers; therefore it recommended that to strengthen it further, the ring-fence should be fortified with more punitive regulatory measures, dubbed as 'electrifying the ring-fence'. This 'electrification' seems to be an innovative idea to solve the problems envisaged; however, it is argued that this idea is not without theoretical problems of its own. Also, it is suggested that to solve behavioural and structural problems within banking institutions, the Act could have benefited from a regulatory regime based on the concept of 'whistle-blowers' and economic incentives, also found in section 922 of the Dodd-Frank Wall Street Reform and the Consumer Protection Act (Dodd-Frank Act).
\end{abstract}

\section{PART 1}

\section{IN TRODUCTION}

The Financial Services (Banking Reform) Act 2013 (Banking Reforms Act) (the Act) received Royal Assent on 18 December 2013. The Act implements the final recommendations of the Independent Commission on Banking (the Commission), set up by the government in 2010 to consider structural reform of the banking sector. ${ }^{1}$ The Act, among others, ${ }^{2}$ primarily focuses on the sector's structural problems, and hence

BrunelLaw School, BrunelUniversity, Uxbridge, UK.

Final Report, Recommendations, Independent Commission on Banking, September 2011, http://bankingcommission. independent.gov.uk/

The large UK banking groups are required to hold equity and other regulatory capital to absorb losses. Also, four key areas form the focus of the Banking Reforms Act: supervision, culture, competition, and structure.

( The Author 2015.Published by Oxford University Press.All rights reserved.Forpermissions, pleasee-mail: journals.permissions@ oup.com. 


\section{Page 2of 17 • The Financial Services (Banking Reform) Act 2013: Smart Regulatory Regime?}

recommends structural regulation and a command and control strategy ${ }^{3}$ in the form of 'ring-fencing' - the concept of a firewall between retail, deposit-taking banking, and riskier investment banking. This means that retail banking should be separated from

2.5 wholesale or investment banking within a banking group. ${ }^{4}$ The Act focuses on the principle that it should be easier and less costly to bring about the resolution of a bank when it gets into financial difficulties. This simply means determining which activities of a failing bank must be allowed to continue in an orderly manner. This regulatory strategy is meant to ensure the continuous provision of a vital service to the economy and the

2.10 customers of a bank. ${ }^{5}$ The implicit policy objective is to curtail moral hazard ${ }^{6}$ as well as the idea that the banks could rely on the implicit guarantees of the government as they are seen to be 'too big to fail', ${ }^{7}$ and that the government stands as a lender of last resort ${ }^{8}$ for the failing banks.

At the Bill ${ }^{9}$ stage, the process was joined by the recommendations from the 2.15 Parliamentary Commission on Banking Standards (PCBS), ${ }^{10}$ dubbed as 'electrification' of the ring-fence, meaning a further strengthening of the ring-fence mechanism. The PCBS published its report on the draft Bank Reform Bill on 11 March 2013, ${ }^{11}$ whereby it challenged the government's reform of the banking industry. The PCBS was of the opinion that the government's reform of the banking industry fell short of what was 2.20 required. ${ }^{12}$ The PCBSidentified a number of challenges that a new structural framework (ring-fence) for banks would face. ${ }^{13}$ In view of these challenges, the PCBS believed that the ring-fencing proposals as they stood in the Bill might 'not be sufficient to achieve the government's policy objectives. ${ }^{14}$ The PCBS recommended 'a series of measures to

3 B Morgan and K Yeung, An Introduction to Law and Regulation (CUP 2007), 80-85; R Baldwin and M Cave, Understanding Regulation (2nd edn OUP 2012), 106-107; R Baldwin, 'Regulation: After Command and Control', in K Hawkins (ed.), The Human FaceofLaw (OUP1997); TDaintith, 'The Techniques of Government' in Jowell andD Oliver(eds.), The Changing Constitution (Oxford: Clarendon Press), 209-236; C Veljanovski, 'Economic Approaches to Regulation', in R Baldwin, M Cave and M Lodge, The Oxford Handbook of Regulation (OUP 2010), 27-28 and 33-34; see also C Coglianese and E Mendelson, 'Meta-Regulation and Self-Regulation', in R Baldwin, M Cave and M Lodge, The Oxford Handbook of Regulation (OUP 2010), 146-151.

$2.30 \quad{ }^{4} \quad$ See MBlair, GWakerand R Purves, FinancialServices Law (OUP 2014), 648-652.

The Government response to the ICB recommendations was published on 19 December 2011; see Cm 8252 Government response to the Independent Commission on Banking. Further developed Government proposals were set in the White Paper, $\mathrm{Cm} 8356$ Banking reforms: delivering stability and supporting a sustainable economy.

6 R Baldwin and M Cave, (n 1) 20; IG MacNeil, An Introduction to The Law on Financial Investment (Hart 2012), 31-32; see generally, G Calabresi, The Cost of Accidents: A Legal and Economic Analysis (New Haven 1970).

See generally, E Greene et al., 'A Closer Look at 'Too big to Fail': National and International Approaches to Addressing the Risk of Large, International Financial Institutions'Capital Markets Law Journal 2(5), 117; AR Sorkin, Too Big to Fail, (Harmondsworth: Penguin 2010).

8 TM Humphrey and RE Kelcher, 'The Lender of Last Resort: A Historical Perspective' Cato Journal 4, 275; X Freixas, C Giannini, G Hoggarth and F Soussa, 'Lender of Last Resort - A Review of the Literature', in C Goodhart and G Illing (eds), Financial Crisis, Contagion, and the Lender of the Last Resort (OUP 2002); A Campbell and R Lastra, 'Revisiting the Lender of Last Resort-The Role of the Bank of England', in I MacNeil and O'Brien (eds), The Future of Financial Regulation, 2010, $161-178$.

9 The Bill was published on 10 October 2012 in Cm 8453 Sound Banking: Delivering Reform. This was to enable pre-legislative scrutiny of the Bill by the PCBS.

10 See PCBS First report (HL98-HC848), Second report (HL 126-HC 1012) and the Final report, Changing Banking for Good (HL 27-1-HC175-1).

$2.45 \quad$ HL Paper 126 HC 1012.

2.46 First Report Paras 63-78, (n 11) and HL Paper 98 of Ression 1012

${ }^{14}$ FirstReport,para94(n11). 


\section{The Financial Services (Banking Reform) Act 2013: Smart Regulatory Regime? • Page 3 of 17}

reinforce the ring-fence in order to increase the prospect of it proving durable in the long-run'15 and '...to create a significant new disincentive for banks seeking over time to test the ring-fence with a view to undermining its effectiveness' ${ }^{16}$

In this context, the PCBS made two distinct recommendations to be included in the Bill in terms of 'first and second reserve powers' (electrification provision). These two reserve powers, punitive in nature, were meant to deter bankers from unscrupulously breaching the ring-fence. These recommendations were the specific proposals for 'electrification' of the ring-fence of banks, implying that banks need to be incentivized to respect the integrity of the ring-fence. ${ }^{17}$ The first recommendation ${ }^{18}$ (first reserve power) is included in the $\mathrm{Act}^{19}$; however, the second ${ }^{20}$ recommendation (second power), which was to exercise full separation across the banking sector as a whole, meaning to enforce a complete structural separation across the sector, was ignored by parliament. ${ }^{21}$ Thus, the Act includes government's reform of the banking industry in respect of 'ring-fencing' and 'electrification' of ring-fencing, with a watered-down version ofelectrification.

The Banking Reforms Act is a unique milestone in the history of banking regulation in the United Kingdom. The prior banking regulation in the United Kingdom, since the hay days of self-regulation, ${ }^{22}$ unlike the US regulatory culture, ${ }^{23}$ was largely

15 See Second Report, para 5; also First Report, para 126. The Commission's report was supported by Sir John Vickers as to increasing the durability and permanence of the ring-fence (quoted in Second Report, para 5)

16 See Second Report, para 8

${ }_{17}$ A Tyrie MP said that ' $[\mathrm{F}]$ or the ring-fence to succeed, banks need to be discouraged from gaming the rules. All history tells us they will do this unless incentivised not to',21 December 2012, The Telegraph.

18 Second Report, para 10: The first power would 'enable the regulator to take steps that could lead to a specific banking group affected by the ring-fence being required to divest itself fully of either its ring-fenced or its non-ring-fenced bank. This power could thus be exercised in respect of an individual bank (or more than one if necessary) while retaining the benefits across the sector as a whole of diversification...'

Second Report, para 11: An individual banking group could be obliged to full separation of retail and wholesale activities. See, how the first reserve power might work, and also several safeguards: ' a) A stipulation that the regulator could only commence the process if it felt there was a significant risk to the objectives of the ring-fence; b) A provision that the power would not be exercisable before the first independent review of the effectiveness of the ring-fence (an independent review which we discuss in the next section of this Report); c) A requirement for the regulator to give a banking group early notice of any intention to use the reserve power; d) The appointment of an external reviewer to consider the relationship between the banking group concerned and the regulator; e) A right of appeal in relation to the exercise of the power; and f) A Treasury power to override implementation.'

19 See FSMA 2000, section 142.

20 Second Report, para 25: 'Alongside our proposal for a group-specific regulatory power to enforce full structural separation, we recommended that the independent review should be required to assess the case for a move to full separation across the banking sector as a whole'. See also First Report, paras 164, 171.

${ }_{21}$ Second Report, paras 25-28. The government rejected the case for a 'second reserve power on various grounds: 'First, it contends that passing such legislation would entail the Government pursuing a 'different policy' from that contained in the Bill, a policy which in the Government's view would be based on the assumption that the ring-fence might fail, when the Government does not itself believe that the ring-fence will fail. Second, the Government argues that 'it is not necessary to legislate now for a reserve power to abandon ring-fencing at some point in the future', because this is a decision best made by Government and Parliament at the time. Third, it contends that it would be wrong for the final decision on whether to bring in such a radical change to be in the hands of the regulator rather than for Government and Parliament.' (Second Report, para 26).

22 Before 1979, with some exceptions, a deposit-taking institution in the United Kingdom did not require any licence or authorization: see Lord Steyn eloquently elaborates this fact in his judgment in Three Rivers District Council and Others v Governor and Companyofthe BankofEngland(HL)18May2000,2000WL571203;CHadjiemmanuil, 'TheBank of Englandand the Lessons from Barings: UK Banking Regulation under Parliamentary Scrutiny', 1 Y.B.Int'lFin. \& Econ. L. $1996,333$.

23 Theidea of separation of commercial and invest banking first appeared in National Bank Act of 1866 and it was reintroduced in Glass-Steagall Act of 1933 and finally again in Dodd-Frank Act 2010. 


\section{Page4 of 17 • The Financial Services (Banking Reform) Act 2013: Smart Regulatory Regime?}

non-structural in nature and did not require the separation of commercial and investment banking; the experiment of such structural regulation in the United States can be traced back to National Bank Act of 1866. The Financial Services and Markets Act 2000 (FSMA) and the regulatory response ${ }^{24}$ to the 2007-08 financial crisis in the form of

4.5 the Banking Act 2009 were believed to be insufficient for the regulatory requirements of the present times. The Banking Reforms Act, in this sense, ushers in the new era of financial regulation and makes a clear-cut watershed in the development of banking regulation in the United Kingdom.

However, this article highlights the theoretical shortcomings of the idea of electrifi-

4.10 cation of the ring-fence and questions its necessity as a corrective regulatory tool. Also, it is argued that the emphasis on structural regulation in the context of electrification leaves out some of the important behavioural issues. Behavioural regulation ${ }^{25}$ is equally important as compared to structural regulation, as is manifested across the developed world. ${ }^{26}$ In this context, the article advocates the usefulness of the concept of 'whistle-

4.15 blowers' as an alternative regulatory tool to the costly and disruptive solution of 'electrification of ring-fence'.

Part 1 deals with the definitional issues of ring-fencing as well as the justification, theoretical basis and strategy of regulation in the context of ring-fencing regulation as found in the Act. Part 2 deals with the idea of 'electrification'. Part 3 deals with the idea 4.20 of 'a whistle-blower'. Finally, the article concludes that the idea of 'electrification' has its own theoretical shortcomings and that the Act should have included the idea of 'whistle-blower' provisions, incentivizing employees as a major strategy of regulation.

\section{RING-FENCING AND THE 'ELECTRIFICATION' OF} THE RING - FENCE

\section{A. Defining the Ring-Fence}

Ring-fencing is a relatively old concept, which has been used as a trouble-shooter or panacea to solve problems in a number of sectors. It has been used as a regulatory solu4.30 tion in banking and many other utility sectors; however, since the 2007 financial crisis, it has been a buzzword for financial regulatory reform across many jurisdictions. Perhaps this is the only idea available that has been well tested and immortalized in a number of past regulatory reforms. In the context of financial regulation, the idea first came to light as a concept in the United States in the National Bank Act of 1866; it 4.35 introduced an idea of partial separation of the banking sector. Then, in the aftermath of the Great Depression, the concept of the ring-fence gained further impetus and was introduced in the legislative form in the Glass-Steagal Act; this introduced the idea of complete structural separation of investmentand commercialbanking. In the aftermath of the 2007-08 financial crises, finally, yet again, ring-fencing took centre stage in the

4.40 Dodd-Frank Act 2010. So, the nature of regulation in this context has long been settled in favour of partial or complete separation. The concept of ring-fencing may not sound

CAE Goodhart, The Regulatory Response to the Financial Crisis', Edward Elgar, 2009.

E Avgouleas, 'What Future for Disclosure as a Regulatory Technique? Lessons from Behavioural Decision Theory and the Global Financial Crisis' in MacNeil and O’Brien (eds) (n 9), 205-225.

$4.45 \quad$ For example, whistle-blower regulation in Dodd-Frank Wall Street Reform and Consumer Protection Act and SOX. See 


\section{The Financial Services (Banking Reform) Act 2013: Smart Regulatory Regime? • Page5 of 17}

an innovative idea; however, its functional application may refute that argument. For example, the place and height of the ring-fence in the Banking Reform Act itself, as discussed below, is innovative.

Ring-fencing is a financial regulatory concept when used for financial institutions, including banks. In conceptual terms, the ring-fencing primarily means reorganizing the allocation of risk ${ }^{27}$ optimally for the purpose of reducing the risk that is associated with the activities of a company. ${ }^{28}$ However, the question is how one can define ringfencing as a financial regulatory concept in a legal sense. It has always been difficult to form an abstract definition of a concept which has a number of functional applications, let alone in law but in other disciplines as well; therefore the unsurmountable problem is 'the lack of an agreed-upon methodology on how to... define legal concepts. ${ }^{29}$ Ringfencing is a functional concept rooted in pragmatism with real economic consequences and is incapable of normative definition ${ }^{30}$; the functional approach avoids unwanted interpretations. ${ }^{31}$ So, the concept of a ring-fence should be defined functionally, taking into account all the intended functions of a ring-fence. For example, if the functions of the ring-fence are to make a firm's bankruptcy remote, to help a firm operate on a stand-alone basis, to preserve a firm's business and assets, or to limit a firm's risky activities and investment, then the concept of ring-fencing should be defined accordingly. Notwithstanding, in all these cases regulation is used to reallocate the risk optimally for the purpose of reducing risk for the companies.

Because the concept is used in different contexts and scenarios, its definition and specific application each time are different. So, each context or scenario produces its own 'functional definition' by answering a simple question — what is the 'function' of a particular ring-fencing, and, in other words, what is the function of a particular regulatory reform? What are the objectives that these functions will achieve? So, in a theoretical analysis, if the aim of the ring-fence is to achieve stability, the functions or objectives of the ring-fence are to achieve that particular aim and the strategies to achieve these objectives are the methodologies. ${ }^{32}$

Thus, one can argue that ring-fencing is a functional financial regulatory concept regarding financial institutions, which entails economic consequences. ${ }^{33}$ The lack of an agreed-upon methodology regarding how to define this legal concept normatively causes problems, ${ }^{34}$ and it can therefore only be defined in view of its functions. Because the concept can only be understood due to its foundation in a common practice in the context of banking and finance, ideally that is how this should be defined rather than in

See generally J Black. 'The Role of Risk in Regulatory Process', in R Baldwin, M Cave and M Lodge, (n 1) p 302; 'The term is also used in a regulatory sense to describe a way of managing a corporation where certain parts of the business could be ring fenced to ensure that losses in one part did not affect another', See Financial Times Lexicon.

${ }_{28} \quad$ SLSchwarcz, Ring-fencing, 87S.Cal.L. Rev, (2013), 5.

29 L Kahler, 'The Influence of Normative Reasons on the Formation of Legal Concepts' in Concepts in Law 81, 90 (JC Hage and D Pfordten eds., 2009); See also, D Patterson, Dworkin on the 'Semantics of Legal Political Concepts,' [2006] Oxford Journal of Legal Studies 26, 552, 553 .

30 SL Schwarcz (n 28) p 14; See also, SL Schwarcz, What is Securitisation? And for What Purpose? [2012] The Southern California Law Review, 1283, 1289.

31 L Kahler (n 29) 90, '[i] fall concerned people understand concepts A, B and C in a specific way due to their foundation in ... common practice, it is preferable to use them rather than the more abstract concept of $\mathrm{D}$ that contains $\mathrm{A}, \mathrm{B}$ and $\mathrm{C}$.'

SLSchwarcz(n28) 5-6,15.

Ibid.

L Kahler (n 29) 90. 


\section{Page6 of 17 • The Financial Services (Banking Reform) Act 2013: Smart Regulatory Regime?}

a normative sense, which would be a mere abstraction and would lack usefulness. Once the functions of the ring-fence have been identified and the concept of ring-fencing has adequately been defined from its functional perspective, then and only then should the regulation be designed and defined accordingly.

6.5 The Banking Reforms Act adopts the functional definition of the concept of ringfencing; it espouses the idea of ring-fencing of certain activities. ${ }^{35}$ The important issues relating to the ring-fence are its location and height in a given context to achieve the objectives of the legislation. All household and Small and Medium-sized Enterprises (SME) deposit-taking and current account provision must take place within the ring-

6.10 fenced bank, and the ring-fenced banks are barred from operating a range of wholesale and investment banking activities. A num- ber of provisions in the Act relate to the 'location' of the ring-fence, about defining, and allowing the government to define, concepts and activities, ${ }^{36}$ and also determine which activities must or must not be carried out within the ring-fenced banks. ${ }^{37}$

6.15 The relevant provision in the Act regarding the 'height' of the ring-fence requires the regulator to make rules for a ring-fenced bank, ensuring that it can work independently of the group and that the ring-fenced banks' core activities are not jeopardized by the acts or omissions of other persons; the rules must also cover intra-group exposures, independent corporate governance, and payment of dividends. ${ }^{38}$ The 'electrification' regulation is

35. Financial Services (Banking Reform) Act 2013, Explanatory Notes: 'section 4: Ring-fencing of certain activities 26 Section 4(1) inserts new Part 9B (ring-fencing) into FSMA.

27 New section 142A(1) defines 'ring-fenced body' for the purposes of FSMA, as any UK institution which carries on at least one core activity for which it has been given a Part 4A permission under FSMA. Subsection (2) excludes building societies from the definition of 'ring-fenced bodies' and gives the Treasury power to exclude other institutions from the definition by order. This power will enable the Treasury to provide that only banks above a certain size will be required to be 'ring-fenced bodies'. Subsection (3) sets out the condition which must be satisfied before the Treasury is able to make such an order: the Treasury must be satisfied that excluding the classes of institution in question from the definition of a ring-fenced body would not harm the continued provision in the United Kingdom of core services. Subsection (4) requires the Treasury to consider the impact the exercise of their powers to exempt certain UK institutions from the definition of 'ring-fenced body' might have on competition in the provision of core services, and whether any adverse impact might be mitigated. Subsection (6) allows the Treasury to set conditions on the grant of an exemption from the definition of a 'ring-fenced body', and subsection (7) defines 'UK institution' for the purposes of the section.

28 New section 142B defines 'core activity' for the purpose of FSMA. Subsection (2) provides that the regulated activity of accepting deposits is to be a core activity, but also gives the Treasury power to provide for exceptions to this, by making an order setting out circumstances in which accepting deposits is not to be treated as a core activity. The Treasury therefore have power to provide (for example) that accepting deposits of high net-worth individuals, or large corporate entities, is not a core activity, so that such deposits may be held in banks which are neither ring-fenced bodies nor exempt under section $142 \mathrm{~A}(2)$ from the obligations that apply to ring-fenced bodies'. See also, Schwarcz (n 10) 5-6, 14-15.

36 The Act also provides the Treasury with a range of delegated powers: (i) Defines a class of institutions which should not be regarded as 'ring-fenced bodies 'even if they otherwise meet the definition (section 142A(2)(b)); (ii) Defines circumstances in which accepting deposits is not to beregarded as a 'coreactivity' (section 142B(2)); (iii) Defines circumstances in which a regulated activity other than accepting deposits is to be regarded as a 'core activity' (section 142B(5)); (iv) Defines circumstances in which dealing in investments as principal is not to be regarded as an 'excluded activity' (section 142D(2)); (v) Add any other activity to the definition of 'excluded activity' (section $142 \mathrm{D}$ (4)); (vi) Impose prohibitions on what a 'ring-fenced body' can do in relation to specific categories of transaction, establishing branches in specific countries, or holding shares in companies of a specified type (section 142E).

${ }_{37}$ See The Act (inserted provisions in the FSMA 2000 as follows: (i) Defines a 'ring-fenced body' as one which conducts 'core activities' (section142A); (ii) Defines the regulated activity of accepting household and SME deposits as a 'core activity' (section 142B); (iii) Defines the regulated activity of 'dealingininvestments as principal'as an 'excluded activity' (section 142D); (iv) Establishes that any 'ring-fended body' which carries on an 'excluded activity' is in breach of its regulatory requirements (section $142 \mathrm{G}$ ).

38 FSMA, 142H. This is the only section of the Act which refers to the 'height' of the ring-fence. 


\section{The Financial Services (Banking Reform) Act 2013: Smart Regulatory Regime? • Page 7 of 17}

designed to prohibit certain kinds of behaviour or demand some positive actions from a financial institution. Non-compliance with these regulations results in serious sanctions.

Arguably, 'electrification' of ring-fencing represents 'a crucial building block for establishing a safer and more secure banking system in the United Kingdom... (which)

could bring significant benefits for public policy and for banking. ${ }^{39}$ The Prudential

Regulation Authority's (PRA) general objective is to promote the safety and soundness of the institutions that it regulates. ${ }^{40}$ The general objective is reflected in the Act and it reflects the implicit policy objective

of curtailing the moral hazard.

\section{B. 'Electrification' of the Ring-Fence}

There is a widely held fear that bankers will aim to undermine ring-fencing by getting around the new legislation ${ }^{41}$; this view is based on the theory that private individuals will always seek to subvert the workings of regulations to benefit themselves. ${ }^{42}$ Without a clearly defined ring-fence, there is a risk that bankers will be able to pull the wool over the eyes of the regulators. For example, the ring-fencing attempts by the National Bank Act of $1866^{43}$ and the Glass-Steagall Act of $1933^{44}$ were frustrated by the banks establishing investment affiliates to get around the prohibition, ${ }^{45}$ and by intense bank lobbying, which paved the way for the repeal of key provisions of the Glass-Steagall Act in $1999 .{ }^{46}$ Even before the repeal, the ring-fence was seriously weakened by the interpretation of the legislation through negotiations between the financial institutions and the regulators. ${ }^{47}$ In this type of negotiations, the judgment of regulators often ends up losing ground in favour of powerful lobbying and interest groups, and the regulation often ends up being 'captured'. ${ }^{48}$ This clearly amounts to subversion of justice. ${ }^{49}$

39 Parliamentary Commission on Banking Standards, Second Report, HC (2012-13) p 3 and HL Paper 126 of session 1012. [Second Report].

40 Second Report, paras 29-30.

41 Mervyn King, before Banking Standards Commission, FinancialTimes, 22/23 November 2012.

42 EL Glaeser and A Shleifer, 'The rise of the Regulatory State' [2003] Journal of Economic Literature XLI, 401.

43 The National Bank Act 1864 established the OCC and the federal bank charter; it introduced limitations on bank's capacity to engage in non-banking activities which ring-fenced the banks prior to the US deposit insurance. Before that a number of States that had banking charters (e.g. New York) had same type of provisions.

44 The Gramm-Leach-Bliley Act, also known as the Financial Services Modernisation Act of 1999 [enacted on November 12 1999] repealed part of the Glass-Steagall Act of 1933. The repeal removed barriers in the market among banking, securities, and insurance companies that prohibited any one financial institution from acting as any combination of an investment bank, a commercial bank and an insurance company. Gramm-Leach-Bliley Act enabled commercial banks, investment banks, securities firms, and insurance companies to consolidate under one roof.

45 Toget around the ring-fence most banks created affiliates. For example, National City Bank in 1911 and Chase National Bank in 1917 , both established affiliates that wereable to transact securities business through their 'parent' banks prohibited from. National City Bank being a New York state charted bank and Chase National Bank being a NationalBank were subject to the NationalBank Act.

46 See generally, JG Benston, 'Is Government Regulation of Banks Necessary?'[2000] Journal of Financial Services Research 18(2/3), 186.

${ }^{47}$ For example, The Glass-Steagall Act was chipped away by a series of administrative developments and rulings which allowed commercial banks to indulge in investment activities, see F Tregenna, 'The Fat Years: The Structure and Profitability of the US Banking Sector in the Pre-Crisis Period' Cambridge Journal of Economics 33(4), 609-632.

48 See 'capture' or 'special interest' theories of regulation: G Stigler, 'Theories of Economic Regulation' [1971] Bell Journal of Economics, 3-21; S Peltzman, 'Toward a More General Theory of Regulation' [1976] The Journal of Law Economics 19(2), 211; F McChesney, 'Rent Extraction and Rent Creation in the Economic Theory of Regulation' [1987] Journal of Legal Studies 16(1), 101. These authors question the motives and capabilities of the regulators.

49 EL Glaeser and A Shleifer, 'The Rise of the Regulatory State'Journal of Economic Literature, American Economic Association 41(2), 401-425, June, 401. 


\section{Page8 of 17 • The Financial Services (Banking Reform) Act 2013: Smart Regulatory Regime?}

To deal with the concerns of regulation being captured or frustrated in any way, the threat of 'electrification' was introduced in the Act. ${ }^{50}$ This could be a powerful tool in the regulator's kit to ensure the independence and integrity of a ring-fenced bank. However, this will allow different banking models to operate alongside each other; and, 8.5 it does not explain how this would enhance the performance of the institution itself.

AQ7 The PRA and Financial Conduct Authority (FCA) are vested with restructuring powers; they can require banking groups to restructure their operations where they find that a ring-fence is proving to be ineffective. There are four circumstances in which group restructuring powers become exercisable. ${ }^{51}$ These measures were 8.10 thought to be appropriate in the public interest. ${ }^{52}$

However, the exercise of the above powers by the PRA and FCA has an inherent potential to cause groups to split their commercial (retail) and investment banking operations into separate corporate groups. Such a separation is effected by the steps that the ring-fenced body may be required to take..$^{53}$ FSMA 2000, section 142L, also

8.15 affords for the situation where the PRA or FCA needs to impose a requirement on an entity for which it is not the appropriate regulator. ${ }^{54}$

This plainly punishes an institution which may otherwise be structurally sound; the deconstruction of an institution carries disastrous consequences. This kind of extreme 'boil them in oil' approach to enforcement of regulation entailing high penalties ${ }^{55}$ is

51 Financial Services (Banking Reform) Act 2013, section 142K Cases in which group restructuring powers become exercisable

'(1) The appropriate regulator may exercise the group restructuring powers only if it is satisfied that one or more of Conditions $\mathrm{A}$ to $\mathrm{D}$ is met in relation to a ring-fenced body that is a member of a group. (2) Condition $\mathrm{A}$ is that the carrying on of core activities by the ring-fenced body is being adversely affected by the acts or omissions of other members of its group.

(3) Condition B is that in carrying on its business the ring-fenced body-(a) is unable to take decisions independently of other members of its group, or(b) depends on resources which are provided by a member of its group and which would cease to be available in the event of the insolvency of the other member.(4) Condition $\mathrm{C}$ is that in the event of the insolvency of one or more other members of its group the ring-fenced body would be unable to continue to carry on the core activities carried on by it. (5) Condition D is that the ring-fenced body or another member of its group has engaged, or is engaged, in conduct which is having, or would apart from this section be likely to have, an adverse effect on the advancement by the appropriate regulator- (a) in the case of the PRA, of the objective in section $2 \mathrm{~B}(3)$ (c), or(b) in the case of the FCA, of the continuity objective.'

52 See generally B Morgan and K Yeung (n 4), 17-36; C Sunstein, 'After the rights revolution: reconceiving the regulatory state (Cambridge (MA): Harvard University Press 1990); T Prosser, Nationalised Industry and Public Control: Legal, Constitutional and Public Issues (Oxford: Blackwell 1986); S Croley, 'Theories of regulation: Incorporating the administrative process' [1998] 98 Columbia Law Review 1, 56-65.

8.35 Financial Services (Banking Reform) Act 2013, section 142L (5) and (6): (5) The steps that the ring-fenced body may be required to take are- (a) to dispose of specified property or rights to an outside person; (b) to apply to the court under Part 7 for an order sanctioning a ring-fencing transfer scheme relating to the transfer of the whole or part of the business of the ring-fenced body to an outside person; (c) otherwise to make arrangements discharging the ring-fenced body from specified liabilities. (6) The steps that another authorised person or a qualifying parent undertaking may be required to take are- (a) to dispose of any shares in, or securities of, the ring-fenced body to an outside person; (b) to dispose of any interest in any other body corporate that

8.40 is member of the ring-fenced body's group to an outside person; (c) to dispose of other specified property or rights to an outside person; (d) to apply to the court under Part 7 for an order sanctioning a ring-fencing transfer scheme relating to the transfer of the whole or part of the business of the authorized person or qualifying parent undertaking to an outside person.

54 See Financial Services (Banking Reform) ACT 2013, Explanatory Notes, no.45, furthermore: 'The PRA is given power to require the FCA to impose the relevant requirement. The FCA is given an equivalent power where it is the appropriate regulator, and it wishes to impose a requirement on a PRA-authorised person. The powers set out in this section include a power to require a ring-fenced body to make arrangements discharging it from liabilities specified by the regulator (subsection (5)(c)). 
rarely workable because there will be a stronger desire for 'capture' and subversion of justice. $^{56}$

Besides, the fundamental fault with this reasoning is that it wholly relies on regulation and shuts the door on criminal and tort law taking effect against the individuals who cause the breach of the ring-fence and harm the banking institution; ${ }^{57}$ the principles of strict liability, negligence, and fraud can also play important roles. ${ }^{58} \mathrm{~A}$ mix of regulation and litigation is needed in the sector. ${ }^{59}$ Regulation organizing private litigation can be beneficial for financial market development, for example, rules that lower the cost of litigation and facilitate litigation.

The largest banks face the constant threat of being split up if they undermine the purpose of the ring-fence and present a risk to the financial system. The threat of being broken up is likely to cause regulatory uncertainty and uncertainty for investors and makeitharder for those banks to raise money, which could then beloaned to businesses.

The wider theoretical and practical implications are that this element of uncertainty could contribute to a market failure in a devastating way. ${ }^{60}$ For example, if a bank is under scrutiny in the context of electrification, news of it being broken up could spread panic in the market place among the investors and shareholders, which could ultimately cause a run on the bank. So the electrification scrutiny could easily itself cause a market failure; any view contradicting this argument is not based on any empirical views - they simply amount to personal views and lack theoretical depth. $^{61}$

Also, there is actually a public policy issue here which militates against the 'electrification' power provisions in the Act and deserves attention. The construct of the 'electrification' powers in the Act allows public policy to be changed by the regulators. The fact that, effectively, the electrification provisions would allow the regulator to introduce a full separation of retail and investment banking within the groups actually amounts to modifying public policy without recourse to parliament, and it seems to be unreasonable. Although Parliament can confer legislative

$56 \quad$ EL Glaeser and A Shleifer (n 49), 403.

57 Ibid (n 49), 404-408; L Friedman, A History of American Law, NY: Simon and Schuster, 1985; RA Posner, 'A Theory of Negligence' [1972] The Journal of Legal Studies 1(1), 29-96.

58 EL Glaeser and A Shleifer (n 49), 401-404.

59 M Arnold, 'Prosecuting bankers would be a start', Financial Times, August 4, 2014; J Rakoff (a US district judge): 'I suggest that the future deterrent value of successfully prosecuting individuals far outweighs the prophylactic benefits of imposing internal compliance measures that are often little more than window-dressing'

${ }_{60}$ See generally FM Bator, 'The Anatomy of Market Failure', Quarterly Journal of Economics 72, 351-79351; R Cooter, 'Normative Failures Theory of Law' [1996] Cornell Law Review 82, 947, 949; RO Zerbe Jr and HE McCurdy, 'The Failure of Market Failure' [1999] Journal of Policy Analysis and Management, 558, 559.

61 See, for example, the oral evidence of Antonio Horta-Osório, Group Chief Executive, Lloyds Banking Group, taken before the Parliamentary Commission on Banking Standards (Question no. 3421, HC 606-xxx1). He disagreed with the BBA's opposition to electrification. He said:

'We were not notified about those comments, which I think were made by the CEO of the BBA in his name. I support electrification, like I supported ring-fencing. As you know, we were the only bank publicly to support ring-fencing. The reason why I support your proposal is that, if we think that for society as a whole it is better to have ring-fencing, both from a financial stability point of view and from a cultural point of view, I absolutely agree that you should have strong enforcement and strong incentives in order for that to happen', Second Report, para 15; See also both Sir David Walker, Chairman of Barclays and Douglas Flint, Executive Chairman of HSBC, also supported the proposal for the first reserve power, the latter saying: 'In the event that it is judged that participants are circumventing or frustrating the purpose of the ring-fence, it seems to me quite reasonable for there to be a sanction.' 


\section{Page 10 of 17 • The Financial Services (Banking Reform) Act 2013: Smart Regulatory Regime?}

powers on the regulator, it is uncharacteristic that in this case the regulator would actually be exercising parliamentary powers, because it is parliament only which can make and change public policy. Thus, the provisions on electrification are anomalous.

10.5 In this public policy debate, the central question is why ring-fencing (partial structural separation) was preferable over total separation in the first place? Maybe it is designed to enable a non-ring-fenced investment entity in a banking group to inject money into a ring-fenced retail institution that got into trouble. There must be many other benefits that were envisaged in the choice of partial

10.10 structural separation because it is inconceivable that the preference of partial separation happened to come about at the centre stage without any other reasons for such public policy. ${ }^{6}$ If partial structural separation is removed and replaced with full structural separation, what happens to the thinking behind the partial structural separation on which the whole structure of public policy was built upon?

10.15 The whole logic of it stands on its head and it remains an unexplained. Besides, what is the point of full structural separation? The idea that full separation of retail and investment banking would make the financial system safe was unrealistic. This over-interprets the benefits of full separation, and the economy could still be blown up by failures of investment banks or the shadow banking sector. ${ }^{63}$

10.20 The benefits of public policy advocating full separation are neither fully analysed nor understood.

Furthermore, the kind of behaviour that will invite the enforcement of electrification provisions of the Act against a bank could not be regarded as 'institutional behaviour'; rather, it must be an individual behaviour of the employees. First, it 10.25 is illogical to 'punish' the institution for the wrongdoings of a few individuals and bring about further structural change; there is no theoretical justification for such a reaction. Furthermore no studies have been carried out to inform us or enable us to comprehend what the consequences of such a change across the national economy would be for wider society and global relationships. To deal with indi-

10.30 vidual behaviour, it may be argued that the specific behavioural regulation should suffice, along with the existing common law and company law. ${ }^{64}$ The electrification provisions are equivalent to cracking a nut with a sledgehammer. Second, structural changes should only be brought about for institutional reasons and not otherwise. Thirdly, institutional restructuring must be a public policy issue, with

10.35 the public policy brought about by parliament in the form of legislation; it is not something that could or should be changed or implemented by regulators. It may be a perfect argument that parliament could delegate regulatory powers to a regulator; however, these 'electrification' powers have gone too far, putting a regulator in a position to change a public policy, which is supposed to be the prerogative of

10.40 parliament.

${ }_{62}$ ELGlaeser and A Shleifer, (n 49), the authors explain in their 'theory oflaw enforcement,' the reasons for choosing a particular type of regulatory regime.

$10.45 \quad$ PTucker, 'Regulatory Reform, Stability and Central Banking', Brookings Institution Working Paper, 2014.

$10.45 \quad 64 \quad$ G Mitchell, 'Sanctions for Bank Directors and Ring-Fencing' [2013] Butterworth's Journal of International Banking and $10.46 \quad$ Financial Law, 287-289. 
The proposal that there should be an automatic periodic review of the ring-fence legislation every $2 / 3 / 4$ etc. years to make sure that the bankers are not undermining the fence would help create a formidable regulatory system instead of merely relying on the regulators, which are susceptible to 'capture' by special interest groups at a serious cost to the rest of society. Automatic revision of this legislation, although a rare phenomenon, will be justifiable on the basis of public interest, as financial regulation, like the financial industry itself, is a special case. This will also reduce the dependence on and concentration of too much power within the hands of regulators, and would avoid the risk of capture. Such a two-tier system would guarantee the stability of the financial system.

\section{(C) Regulatory Rationale for the Ring-Fenceand the 'Electrification'in the Act}

The Banking Reforms Act emerged as a regulatory response to financial market failures $^{65}$ as a consequence of the 2007-08 financial crisis in the United Kingdom and across the world. The theoretical reasons for this Act are rooted in public interest ${ }^{66}$ and emerged as a regulatory command and control strategy ${ }^{67}$ for the financial sector to ensure its stability. The fundamental nature of command and control is that it displays its influence by imposing standards backed by sanctions. ${ }^{68}$

The command and control strategy is largely exercised by the FCA and PRA. The Act provides the regulators with rule-making powers, which allow them to bring in an even more extensive regime of command and control. The legislation would use force of law to impose inflexible benchmarks. ${ }^{69}$ Politically, this kind of thinking seems astute because the government and the regulators are seen here to be acting forcefully and taking a clear stand in the aftermath of the financial crisis, by describing some forms of institutional behaviour as unacceptable. The public is being assured that the full force of the law would be used to protect their interests and in the interest of the financial system.

However, the command and control strategy can only be justified if the critics are unable to argue for a better alternative strategy. ${ }^{70}$ There are significant inherent problems ${ }^{71}$ associated with the command and control strategy, such as 'capture ${ }^{72}$ and 'legalism' ${ }^{73}$ which the regulation ensuing the Act might face. Strikingly, the Act ignores other enforcementstrategies such as those based on economicincentives. ${ }^{74}$. Expandedincentives for whistle-blowers to report suspected violation of a ring-fence could prove a better alternative to the electrification idea.

65 SeegenerallyFMBator, 'The AnatomyofMarketFailure',QuarterlyJournalofEconomics 72,351-79; RBaldwin andMCave (n 4) 9-16.

${ }_{66}$ M Feintuck, 'Regulatory Rationales Beyond the Economic: In Search of the Public Interest', in R Baldwin, M Cave and M Lodge (n 4) 39-60.

R Baldwin, C Cave; B Morgan, K Yeung (n 4).

RBaldwin, 'Regulation: After Command and Control', in K. Hawkins (ed.), The Human Face of Law (OUP 1997).

BMorgan, KYeung,Seegenerally the 'the roleoflaw' in regulation discussed by the authors, 17-74.

Ibid.

Seegenerally, RB Stewart, 'Regulation on the Crisis of Legalism in the United State', in TDaintith(ed.), Lawasan Investment of Economic Policy, Berlin, 1998; E Bardach and R Kagan, Going by the Book: The Problem of Regulatory Unreasonableness Philadelphia, 1982; N Gunningham and P Grabosky, Smart Regulation (OUP 1998), 44-45.

RBaldwin, MCave (n 4), 36-37.

Ibid 37-38. 


\section{3. . AN ALTERNATIVE TO ELECTRIFICATION: EXPANDED INCENTIVESFOR WHISTLE-BLOWERSTOREPORT SUSPECTED RING-FENCE VIOLATION}

Arguably there are some common law alternatives along with or without regulation ${ }^{75}$; the 'whistle-blower' concept can prove to be a better, simpler, more efficient, ${ }^{76}$ and effective alternative to 'electrification' of ring-fencing. Whistle-blowing is a term of art; it has special meaning in the legal context, as it does in other disciplines; it is a multi-

12.10 disciplinary concept. Hence, it cannot be defined in a normative sense, including all of its multidisciplinary characteristics and virtues. In this sense, it is a multi-disciplinary and functional concept, which can be defined as a process, and to that end includes at least four elements ${ }^{77}$ : the whistle-blower, the act of whistle-blowing, the recipient of the complaint, and the target organization of the complaint. The act of whistle-blowing on

12.15 an organization is an act of resistance ${ }^{78}$ and represents the 'voice' of dissidence. ${ }^{79}$ The act of whistle-blowing has been variously interpreted as providing information about the organizational activities that 'harm third parties" ${ }^{80}$ or 'jeopardize the public interest'. ${ }^{81}$ The concerned activity may involve 'misconduct, neglect, or irresponsibility', 'corrupt, socially harmful, or illegal activity', ${ }^{83}$ or 'wasteful activities' ${ }^{\prime}{ }^{84}$

12.20 The four elements of whistle-blowing on which most authors agree are as follows ${ }^{85}$ : First, the whistle-blower is or has been a member of the organization ${ }^{86}$; second, the whistle-blower is an individual who lacks legitimate authority to change the organization's activities $^{87}$; third, the whistle-blower can sometimes remain anonymous, although this is not without ethical and practical implications ${ }^{88}$; and fourth, the whistle-blower may

75 For example, Litigation for breach of contract, breach of fiduciary duty, doctrine of ultra vires and tort litigation for strict liability and negligence, see AG Mitchell, 'Sanctions for Bank Directors and Ring Fencing' [2013] Butterworth's Journal of International Banking andFinancial Law, 288.

76 EL Glaeser and A Shleifer (n 49) 201-204; G Mitchell (99), 287-289.

77 JP Near and MP Miceli, Organisational Dissidence: The Case of Whistle-Blowing,Journal of Business Ethics 4, 1985, 2; cf. see PBJubb, Whistleblowing: A Restrictive Definition and Interpretation,JournalofBusiness Ethics 21:83 (1999) the author mentions six elements of the proposed definition of whistle-blowing; see also JP Near and MP Miceli, 'Whistle-Blowing: Myth and Reality' [1996] Journal of Management 22(3), 506, The authors accept three elements of whistle-blowing process.

${ }_{78}$ FA Elliston, 'Civil Disobedience and Whistle-Blowing: a Comparative Appraisal of Two Forms of Dissident' [1982b] Journal of Business Ethics 1,23-28.

79 AO Hirschman, Exit, Voice, and Loyalty: Responsesto Decline in Firms, Organizations, andStates (Cambridge, MA: Harvard University Press 1970).

$80 \quad$ FA Elliston (78) 23-28.

81 D Farrell and JC Petersen, 'Patterns of Political Behaviour in Organisations' [1982] Academy of Management Review 7 , 403-412.

82 D Farrell and JC Petersen, Ibid.

83 ILJanis andLMann, Decision Making (New York:FreePress 1977).

${ }^{84}$ United States Merit Systems Protection Board (USMSPB), Whistle-blowing and the federal employee, U.S. Government Printing Office, Washington, DC, 1981.

${ }_{85}$ JP Near and MP. Miceli, 'Organisational Dissidence: The Case of Whistle-Blowing' [1985] The Journal of Business Ethics 4(1), 1-16.

86 D Farrell and JC Petersen (n 81) 403-412; IL Janis and L Mann (n 83); United States Merit Systems Protection Board (USMSPB), Whistle-blowing and the federal employee, U.S. Government Printing Office, Washington, DC, 1981.

87 FA Elliston 'Anonymity and Whistle-Blowing' [1982a] Journal of Business Ethics 1,167-177; D Weinstein, Bureaucratic Opposition (New York: Pergamon Press 1979).

$12.46 \quad 88 \quad$ FAElliston(n78). 


\section{The Financial Services (Banking Reform) Act 2013: Smart Regulatory Regime? • Page 13 of 17}

occupy a role such as an auditor, ombudsman, or any other overseeing role where he/she may be officially required to blow the whistle if he/she observes organizational wrongdoing. ${ }^{89}$ From these four attributes, it may be broadly concluded that the whistle-blower is a person, normally an insider, who provides information regarding regulatory violation. ${ }^{90}$

There is disagreement among authors as to the third element- the nature of the person or agency who receives information - in the whistle-blowing process. Some authorsidentify the appropriaterecipientofinformationin thewhistle-blowingprocess as an external person or agency to the organization..$^{91}$ This amounts to a public complaint; in their view, internal complaint does not truly represent the whistle-blowing process. ${ }^{92}$ However, some authors value internal or external complaint equally, as long as the internal complaint is also made to someone other than the immediate superior. ${ }^{93}$

Any organization, public or private, may be made a target of whistle-blowing. By encouraging whistle-blowing, the organizations will gain additional information that may be used to enhance their operational capabilities. ${ }^{94}$ To this end, whistle-blowing may be broadly defined as disclosure by the members of an organization of illegal and unethical actions by the employers to a person or agency, internal or external which can bring about action against the perpetrators of such illegal and unethical activities. ${ }^{95}$

In the context of the financial sector, the whistle-blower concept has two important aspects. First is that a whistle-blower should be rewarded with a substantial bounty for providing useful information to the regulators regarding regulatory violations; secondly, he/ she should be provided with retaliation protection. ${ }^{96}$ In the United Kingdom, whistle-blowing regulation is still in its infancy. The whistle-blowing interest group Public Concern at Work (PCaW) set up an independent commission in 2013 to review all aspects of whistle-blowing, including legal, governance, and best practice arrangements. In November 2014, it published its report, which made a number of recommendations. The commission, however, did not make any recommendation for the introduction of financial rewards or incentives for whistle-blowing. The commission's recommendations are not specific to any particular sector; rather, they are more general in nature.

In the United States, the concept was introduced more robustly in the Dodd-Frank Wall Street Reform and Consumer Protection Act (Dodd-Frank Act), ${ }^{97}$ although it was

89 JP Near and MP Miceli, ‘Organisational Dissidence’ (n 85).

90 Securities Exchange Act of 1934 (Exchange Act) defines a whistle-blower as an individual or group of individuals ' who provide... information relating to a violation of the securities laws to the Commission, in a manner established, by rule or regulation, by the Commission.' See also section 21 F, ‘Securities Whistle-blower Incentives and Protection', Dodd-Frank Act s 922(a), 124 Stat. at1841-1842.

$91 \quad$ R Nader, PJ Petkas and K Blackwell (eds.), Whistle-blowing: The report on the conference on professional responsibility, Grossman, New York, 1972; D Weinstein (n 87).

92 DFarrell and JC Petersen (n81), 403-412; IL Janis and L Mann(n83).

93 FAElliston(n87), 167-177; AOHirschman(n83).

94 See generally DW Ewing, Do It My Way-Or You're Fired! (New York:John Wiley \& Sons 1983).

$95 \quad$ JP Near and MP. Miceli, 'Organisational Dissidence' (n 77), 4.

96 This concept was introduced in SOX 2002, Pub. L. No. 107-204, 116 Stat. 745 (codified in scattered sections of the US Code); Also in an enhanced form in Dodd-Frank Act, Pub. L. No. 111-203, S 922, 124 Stat. 1376, 1841-49 (2010) (codified at 15 U.S.C. S 78u-6); See R G Vaughn, 'America's First Comprehensive Statute Protecting Corporate Whistle-blowers' [2005] Administrative Law Review 57, 1, 4

97 Pub. L.NO.111-203, 124 Stat. 1376 (2010) (codified in scattered sections of the US Code). Dodd-Frank Act is a vast and sweeping overhaul of the US financial and regulatory system, was signed into law on 21 July 2010 by President Barack Obama. See D Paletta and A Lucchetti, 'Law Remakes U.S. Financial Landscape' [2010] Wall Street Journal, July 16, A1. 


\section{Page 14 of 17 • The Financial Services (Banking Reform) Act 2013: Smart Regulatory Regime?}

introduced 8 years earlier in Sarbanes-Oxley Act of $2002^{98}$ (SOX) in a weaker form. section 299 of Dodd-Frank expands the incentives for a whistle-blower ${ }^{99}$ by obliging The Security and Exchange Commission (SEC), by adding a new provision, to 'pay an award' to whistle-blowers 'who voluntarily provide original information to the com-

14.5 mission that led to the successful enforcement of the ...action'. ${ }^{100}$ Furthermore, in protecting whistle-blowers, new section $21 \mathrm{~F}(\mathrm{~h})(1)(\mathrm{A})$ forbids employers from discharging, demoting, suspending, threatening, harassing, or in any other way discriminating against a whistle-blower 'because of any lawful act done by the whistle-blower in (i) providing information to the SEC, (ii) helping in any SEC investigation or action 14.10 related to such information, or (iii) 'in making disclosures that are required or protected under' any securities law, rule, or regulation'. ${ }^{101}$ The enforcement of this prohibition was further fortified in new section $21 \mathrm{~F}(\mathrm{~h})(1)(\mathrm{B})$ that creates a private right of action for individuals alleging a violation of the anti-retaliation provisions. ${ }^{102}$ This enables whistle-blowers to file a complaint in a district court without first having to exhaust admin-

14.15 istrative options. ${ }^{103}$

Recently, a sudden increase was revealed in whistle-blowing reports sent to FCA following a Freedom of Information request made to the regulator. ${ }^{104}$ FCA figures show that the regulator launched 254 new cases on the basis of whistle-blowers' information in 2012/13 compared with only 148 cases a year earlier; this is an increase of 72

14.20 per cent. The concern of the whistle-blower in the suspected market manipulation is encouraging. It is easily discernable from this pattern that further encouragement to would-be informers, on the basis of reward, would be a successful regulatory strategy.

Whistle-blowing provisions in the Banking Reform Act would have provided a better solution for the financial market failure and for the improvement of the stability

14.25 of the financial system. A similar provision, as in US legislation, in respect of protection against retaliation in the Financial Services (Banking Reform) Act would have proved to be the most influential and effective tool for the protection of the ring-fence. Furthermore, an even better regulation in this respect would be where retaliation protection is available to both those who report information externally to the regulators

14.30 as well as those who report internally to the company (bank) itself. This glaring deficiency exists in the Dodd-Frank Act, with section 922 retaliation protection only applying to those whistle-blowers who report information externally (to SEC), leaving those informers who report internally (to the company) either without protection or only protected by the weaker protection ofSOX.

98 Pub. L. No.107-204, 116 Stat.745 (codified in scattered sections of the US Code).

99 See B Carton, Pitfalls Emerge in Dodd-Frank Bounty Provision, COMPLIANCE WEEK, September 2010, 1-2.; R Levick, A Whole New Ballgame: Dodd-Frank's Whistle-blower Provisions, FORBES (Nov. 2, 2010, 1;53 PM); RG Vaughn, 'America's First Comprehensive Statute Protecting Corporate Whistle-blowers' [2005] Administrative Law Review 57, 1, 4.

${ }^{103}$ Dodd-Frank improves regulatory regime regarding 'whistleblowing' in a number of way, for example, aggrieved employee has more time to file complaint, bring a claim up to 6 years after the has occurred or up to 3 years after becoming aware of the claim (provided the claim is brought within 10 years of the violation) (Dodd-Frank Act s 922 (a), 124 Stat. at 1846 . In contrast SOX requires a complaint to be filed within 180 days of the violation or becoming aware of it (18 USC. S 1514A (b) 
Notwithstanding the benefits of external reporting (Dodd-Frank rule), there are serious reservations about the regulatory success as far as achieving the aims of the regulation. The business and legal communities in the United States, as well as the SEC, have acknowledged the potential for the substantial rewards required by the Act to undermine internal compliance procedures (e.g. by SOX) by causing a race to the SEC for external reporting. ${ }^{105}$ The reward and the two-tier nature of the retaliation protection, that is, external and internal, both autonomously incentivize external reporting. Under Dodd-Frank, a whistle-blower worried about retaliation has an advantage and incentive to report directly to SEC as well as internally at the same time, creating a maximum level of protection against retaliation. Any attempt on new legislation regarding 'whistle-blower provision' incentivizing whistle-blowers to report regulatory violations must take into account this flaw in the design of Dodd-Frank and should address both provisions embeddedinSOXandDodd-Frank.

SOX encourages internal reporting anonymously for corporate wrongdoings through internal disclosure systems and incorporates anti-retaliation provisions for the protection of the whistle-blowers ${ }^{106}$. Section 806 of SOX protects whistle-blowers against external reporting to federal regulators, law enforcement agencies, and committees of congress or its members. ${ }^{107}$ However, it is a far weaker response to deal with the problem effectively, because it only protects those whistle-blowers who provide the information with a 'reasonable belief' that the violation actually occurred. In contrast, the Dodd-Frank offers much more robust protection to the whistle-blower by not limiting its protection to a 'reasonable belief' that the violation actually occurred ${ }^{108}$. However, a serious problem remains in that it extends its protection only to those whistle-blowers who report externally.

Comparatively stronger and more robust protection for a whistle-blower against retaliation if he/she reports the suspected regulatory violations directly to the regulators rather than to the company (bank) would discourage internal reporting, thus weakening institutions' internal compliance and reporting procedures and systems. Equally strong and robust external (to regulators) and internal (to bank) reporting of regulatory violations will play an important role in the early detection and prevention of fraud and other regulatory violations. In this context, it is also important that the term 'whistle-blower' or any other equivalent term is defined broadly to achieve maximum impact, ${ }^{109}$ that is, should protection only apply to 'whistle-blowers' or it should include other reporting sources as well. Forexample, the term 'whistle-blower' is defined narrowly by the SEC. ${ }^{110}$

${ }^{105}$ See Proposed Rules for Implementing the Whistle-blower Provisions of Section 21F of the Securities Exchange Act of 1934, 75 Fed. Reg. 70,488 (proposed Nov.17, 2010) (codified at 17 C.F.R. pts. 240, 249); A letter from the Association of Corporate Counsel to Elizabeth M. Murphy, Secretary of Section 1-2 (15 December 2010), available at http://www.sec. gov/comments/s7-33-10/s73310-126.pdf; A letter from Bus. Roundtable to Elizabeth M. Murphy, Secretary of Secion 2 (17 December 2010) available at http://www.sec.gov/comments/s7-33-10/s73310-142.pdf.

${ }^{106}$ See 15 U.S.C S 78 j-1(m) (4) (B) (2006); See also RM Moberly, 'Unfulfilled expectations: An Empirical Analysis of Why Sabanes-Oxxley Whistle-blowers Rarely Win' [2007] William and Mary Law Review 49(1), 65, 75.

$107 \quad$ 18U.S.C s 1341, 1343-1344, 1348.

108 18U.S.CS 1514 A (a) (1).

${ }^{109}$ The prohibition on retaliation found in new section $21 \mathrm{~F}(\mathrm{~h})(1)(\mathrm{A})$ of the Exchange Act applies only to 'whistle-blower', the term is defined narrowly in new section $21 \mathrm{~F}$ (a)(6) at 1842; it includes only those who provide ' information relating to a violation of the securities laws to the Commission, in a manner established, by rule or regulation, by the Commission'.

(1)




\section{Page 16 of 17 • The Financial Services (Banking Reform) Act 2013: Smart Regulatory Regime?}

The system of retaliation protection for a whistle-blower who is reporting internally (to company) actually and effectively creates an internal monitoring system. ${ }^{111}$ Any lack of retaliation protection to a whistle-blower who is reporting internally would unfortunately work against the goal of the regulation that is designed in respect of the

16.5 whistle-blowing. To the same extent, Dworkin and Callahan have argued, '[i]f... the primary goal of whistle-blowing is reduction of wrongdoing rather than prosecution of wrongdoers, and the speed with which problems are addressed is significant, then internal whistleblowing should be preferred' to external whistle-blowing. ${ }^{112}$ It is further argued that 'when the internal/external question is posed in the context of social-

16.10 psychological research generally, and especially when approached from the perspective of organizational needs and behaviour, there is little doubt that internal whistle-blowing is preferable to external reporting. ${ }^{113}$ This view has been endorsed by the majority of researchers 'as the most effective response to organizational wrongdoing ${ }^{\text {'114; }}$; the research has displayed that the most efficient way of combating occupational fraud is

16.15 a company's internal system of anonymous reporting. ${ }^{115}$ The SEC also agrees with this view that 'internal compliance and reporting system are essential sources of information for companies about misconduct'... if these programmes are not utilized or working, our system of securities regulation will be less effective. ${ }^{116}$ Therefore, both Dodd-Frank and SOX need to be amended to provide equivalent protection for potential whistle-

16.20 blowers, regardless of whether they choose to report externally or internally; and the Banking Reforms Actshould have followed this approach.

Thus, to ensure that the bankers do not breach the ring-fence, it is important to have a robust and effective whistle-blowing system that protects potential whistle-blowers from retaliation and rewards them generously regardless of whether they choose to report inter-

16.25 nally or externally. This is a lesson thatcan belearnt from the dichotomy ofDodd-Frank and SOX. Whistle-blower provision could be the single most important regulation for the protection of investors, financial institutions, and the stability of the financial system as a whole.

Whistle-blowing is a preventive measure, whereas 'electrification' is punitive in nature- - there is no point in dealing with the issue long after the damage has been done

16.30 to the financial system; in such situations, the financial system could even be beyond repair before 'electrification' comes into play. It is far better to prevent the damage happening in the first place. The whistle-blower solution is also cost-effective.

\section{CONCLUSION}

16.35 The PCBS made an argument during the Bill stage that the 'ring-fence' regulation, based on Sir John Vickers' report, fell short of expectations, and that it would be easily

111 See O Lobel, Lawyering Loyalties: Speech Rights and Duties within Twenty-First-Century New Governance’ [2009] Forbham Law Review 77, 1245, 1251.

16.40 $\quad{ }^{112} \quad$ TM Dworkin and ES Callahan 'Internal Whistleblowing: Protecting the Interests of the Employee, the Organisation and Society' [1991] American Business Law Journal 29, 267, 306.

113 Ibid p. 299.

114 Ibid p. 299, N.167. See also, K Rubinstein, 'Internal whistleblowing and Sarbanes-Oxley Section 806: Balancing the Interests of Employee and Employer' [2007-2008] New York Law School Law Review 52, 637, 650; TM Dworkin, and JP Near, 'Whistleblowing Statutes: Are They Working?' [1987] American Business Law Journal 241, 242-243. 
breached by unscrupulous bankers. To deal with the regulation being captured or frustrated in any way, it recommended the threat of 'electrification' in the Bill in the form of two distinct powers for the regulators, namely the first reserve power and the second reserve power. The first power would enable the regulator to take steps that could lead to full separation of retail and investment activities within a group. The first reserve power made it into the Act, whereas the second power was rejected.

However, the fact remains that the regulator would be allowed to change legislation. It is unreasonable that in this case the regulator would be exercising parliamentary powers, because it is parliament alone that can make and change public policy, even if parliament were to confer legislative powers on the regulator.

A better view in this context would be that there should be an automatic periodic review of the ring-fence legislation. This would help to create a formidable regulatory system instead of merely relying on the regulator, which would always be susceptible to 'capture' by special interest groups at a serious cost to the rest of the society. Periodic revision of this legislation, although a rare phenomenon, is justifiable on the basis of public interest and the fact that financial regulation, like the financial sector itself, is a special case; regardless, avoidance of market failures and the stability of the financial system and consequently the stability of the entire economy should be the focus.

Furthermore, to ensure that bankers do not breach the ring-fence, it is also important to have a robust and effective whistle-blowing system and economic incentives in place, which protect the potential whistle-blowers from retaliation and reward them generously, regardless of whether they choose to report internally or externally, as also found in section 922 Dodd-Frank Wall Street Reform and Consumer Protection Act (Dodd-Frank Act). This is a lesson that can be learnt from the dichotomy of DoddFrank and SOX. The whistle-blower provision could be the single most important regulation for the protection of investors, financial institutions, and the stability of the financial system as a whole. Whistle-blowing is a cost-effective and preventive measure, which, if included in such regulation, would certainly enhance the stability of the financial system. 